\author{
Piotr Sękowski \\ Katedra Logiki i Metodologii Nauk \\ Uniwersytet Łódzki \\ epistemologicznypesymista@gmail.com
}

\title{
FORMALNE ASPEKTY ARGUMENTU Z AUTORYTETU
}

\begin{abstract}
ABSTRAKT
Artykuł przedstawia analizę argumentu $\mathrm{z}$ autorytetu. $\mathrm{Z}$ pozoru wydaje się, że jest to argument słaby, bo wsparty nie na rzetelnym dowodzeniu, ale na wiedzy innych. Jednak bliższa analiza zadaje kłam temu przeświadczeniu. Kluczowym elementem argumentu $\mathrm{z}$ autorytetu jest autorytet, na który się powołujemy. Od tego, czy autorytet jest dobrze uzasadniony, zależy czy argument jako całość jest dobry. Argument z autorytetu jest, z przyczyn psychologicznych, bardzo skuteczny, niemniej przemyślany i dobrze skonstruowany może być również argumentem bardzo racjonalnym i wartościowym logicznie. Wszystko zależy od tego, na ile racjonalnie został przyjęty sam autorytet. Jak się okazuje, przyjęcie autorytetu to nie kwestia wyłącznie psychologicznego podporządkowania, ale bardzo często racjonalnej konieczności - w pewnych sytuacjach nie sposób racjonalnie odrzucić autorytet. Należy więc stwierdzić, że argument $\mathrm{z}$ autorytetu poprawnie zastosowany $\mathrm{i}$ wsparty racjonalnie przyjętym autorytetem wbrew pozorom może być argumentem niezwykle racjonalnym. Artykuł jest szczegółową analizą takich zagadnień.
\end{abstract}

\section{SŁOWA KLUCZOWE}

Autorytet, argumentacja, argument z autorytetu, Milgram, Bocheński, Tokarz.

\section{WSTĘP}

Argument z autorytetu jest chyba najczęściej spotykaną formą argumentacji. Sytuacja taka ma miejsce szczególnie we wszelkich formach dyskursu niespecjalistycznego (przez dyskurs niespecjalistyczny rozumiem tutaj każdą formę wymiany informacji, opinii i argumentacji zachodzącą między osobami, które nie są w sprawach, o których mówią, specjalistami; per analogiam dyskurs specjalistyczny będzie wymianą informacji, opinii i argumentacji między specjalistami w dziedzinie, której dyskusja dotyczy), w rozmowach na spotkaniach towarzyskich, w reklamie, w znacznej mierze w polityce etc. 
W sytuacjach towarzyskich podejmujemy często rozmowy na tematy, o których nie wiele wiemy, wtedy często i chętnie sięgamy po opinie ekspertów, również nie od dziś wiadomo, że reklama jest skuteczniejsza, kiedy towarzyszy jej zachęcająca wypowiedź autorytetu, natomiast politycy sięgają po autorytety podczas swych publicznych wystąpień, podczas kampanii wyborczych (dość wspomnieć tutaj od dziewięciu lat przywoływanego w każdym możliwym kontekście Jana Pawła II), a także podczas prac na rozwiązaniami prawnymi (wtedy politycy sięgają po ekspertów z dziedziny ekonomii, prawa, dyplomacji). Jednak również w dyskursie specjalistycznym argumentu $\mathrm{z}$ autorytetu usunąć niepodobna. Większość nabytych przez specjalistów informacji pochodzi od autorytetów z poszczególnych dziedzin. Hydraulik swoją wiedzę posiadł dzięki autorytetom, nie dochodził do niej samodzielnie wyłącznie w oparciu o doświadczenie. Już pobieżny ogląd szeroko rozumianych debat naukowych pozwala zauważyć, jak bardzo również wśród specjalistów, argument $\mathrm{z}$ autorytetu jest rozpowszechniony. Nauka operuje dzisiaj tak ogromnym bagażem informacji, że niepodobna by ogarnął go jeden człowiek. Również w samodzielnej pracy naukowej w ogromnej mierze bazuje się na wypracowanych przez innych wynikach, bez tego niemożliwy byłby rozwój nauki. Już mnogość przypisów i obszerne bibliografia prac naukowych wskazują jak wielkie jest znaczenie specjalistów, jak wielkie znaczenie mają dziś autorytety. Podobnie rzecz ma się w humanistyce.

Sytuacja ta sprawia, że argument z autorytetu w sposób szczególny wart jest uwagi i badania - nie tylko ze względu na to, że posiada niezwykle interesującą z punktu widzenia teorii argumentacji i psychologii strukturę, ale przede wszystkim dlatego, że ma dziś ogromne znaczenie. Analiza problematyki związanej $\mathrm{z}$ argumentem $\mathrm{z}$ autorytetu pozwala prześledzić mechanizm rozpowszechniania informacji. W końcu dogłębne badanie argumentacji z autorytetu może pozwolić na wypracowanie skutecznych metod obrony przed nierzetelnie stosowaną tego rodzaju argumentacją i uwrażliwienie społeczeństwa na niebezpieczeństwa związane $\mathrm{z}$ opacznym i pochopnym powoływaniem się na autorytety, jak również ze zbytnią ufnością wobec autorytetów.

\section{TEORIA AUTORYTETU}

Podstawą zamieszczonych tu analiz jest teoria autorytetu wypracowana przez J.M. Bocheńskiego [por. Bocheński 1974, s. 187-324]. Koncepcja ta jest stosunkowo rozbudowaną teorią, w której odpowiada się na pytania o to, czym jest i jak działa autorytet oraz jakie są rodzaje autorytetu, rozważany jest 
problem delegacji autorytetu, czyli „przekazania” autorytetu innej osobie, zagadnienia nadużycia autorytetu etc. Przedmiotem niniejszego artykułu jest, używając terminologii Bocheńskiego, autorytet epistemiczny, czyli autorytet związany z jakąś dziedziną wiedzy, autorytet $\mathrm{w}$ sensie naukowym, poznawczym (w odróżnieniu od autorytetu deontycznego, który wiąże się z wydawaniem poleceń, autorytet epistemiczny przysługuje profesorowi natomiast deontyczny przysługuje generałowi). Nie przedstawiam całej teorii Bocheńskiego, a jedynie jej fragment dający przede wszystkim wygodną w podejmowanych analizach terminologię.

Bocheński, dość nietypowo, nazywa autorytetem pewną trójargumentową relację. Argumentami tej relacji są: podmiot autorytetu, przedmiot autorytetu i dziedzina autorytetu. Podmiotem autorytetu jest osoba, której autorytet przysługuje, którą potocznie nazywa się po prostu autorytetem. Przedmiotem autorytetu jest osoba, którą można byłoby nazwać „odbiorcą” podmiotu czyli osoba, która przyjmuje do wiadomości to, co podmiot autorytetu jej do wiadomości podaje. Jest i trzeci argument relacji - dziedzina - otóż przedmiot autorytetu nie przyjmuje do wiadomości wszystkiego, co podmiot stwierdza, ale jedynie to, co należy do dziedziny, w której podmiot jest autorytetem [por. Bocheński 1974, s. 204 i 242]. Dla wygody i w zgodzie z intuicyjnym, potocznym użyciem słów, w dalszej części artykułu podmiot autorytetu będziemy nazywać po prostu autorytetem, również podobnie, w razie potrzeby - przedmiot autorytetu będziemy nazywać po prostu przedmiotem, dziedzinę autorytetu - po prostu dziedziną.

W trójargumentowej relacji autorytetu wyróżnić możemy trzy stosunki dwuczłonowe, m.in. stosunek podmiotu do przedmiotu. Stosunek ten jest dwuargumentową relacją przechodnią, przeciwsymetryczną i przeciwzwrotną. Oznacza to, że jeśli w jakiejś dziedzinie osoba $x_{l}$ jest autorytetem dla osoby $y$, to również będzie dla $y$ autorytetem osoba $x_{2}$, pod warunkiem, że $x_{2}$ jest autorytetem dla $x_{i}$; jeśli $x$ jest autorytetem dla $y$, to $y$ nie jest autorytetem dla $x$; jedna osoba nie może być jednocześnie podmiotem i przedmiotem autorytetu.

\section{ARGUMENT Z AUTORYTETU}

Argumentacja to ogół czynności zmierzających w kierunku uzasadnienia jakiejś tezy. Czynności te mogą być wyłącznie mentalne, kiedy sami zastanawiamy się nad jakimś problemem lub podejmujemy jakąś decyzję. Zazwyczaj jednak rozumiemy argumentację jako czynności werbalne podejmowane nie tylko w celu publicznej obrony jakiejś tezy, ale również po to by innych do niej przekonać, albo wręcz nakłonić ich do zgody na proponowane przez argumentującego działania oraz do współuczestniczenia w nich 
[por. Tokarz 2006, s. 124]. Jak zauważa Szymanek [por. Szymanek 2008, s. 37] argumentem jest taka wypowiedź, w której dla uzasadnienia jakiejś tezy $t$ podaje się zbiór zdań $p, q, r \ldots, \mathrm{z}$ których przynajmniej $\mathrm{w}$ opinii osoby formułującej argument teza $t$ wynika (w sensie potocznym).

Szczególnym typem argumentu jest argument $\mathrm{z}$ autorytetu. Jest to taka forma argumentacji, w której tak naprawdę ciężar dowodu zostaje przerzucony na osobę (autorytet) częstokroć nieobecną podczas samej argumentacji. Nie jest wymagane, by dostarczyła ona ten dowód, ponieważ z pewnych względów (o których mowa będzie dalej) zakłada się a priori, że jest ona najprawdopodobniej w posiadaniu zupełnie wystarczającego i przekonującego dowodu (może się nawet zdarzyć, że argumentujący i odbiorca nie byliby w stanie zrozumieć takiego dowodu gdyby został im podany, a jednak skłonni są przyjąć jego konkluzję). Działanie argumentu z autorytetu jest więc dość szczególne, gdyż nie dowodzi się, że jest tak jak głosi teza, ale że dla pewnych racji należy przyjąć, że teza ma dowód, a w następstwie tego należy przyjąć samą tezę.

\section{STRUKTURA FORMALNA ARGUMENTU Z AUTORYTETU}

W najbardziej ogólnym ujęciu struktura argumentu z autorytetu jest bardzo prosta:

$x$ twierdzi, że $p$

zatem: $p$

Oznacza to, że jeśli jakaś osoba $x$ twierdzi, że $p$, to $p$. Schemat ten jest jednak zbyt ogólny i może być w błędny sposób interpretowany, wynika z niego bowiem, że argumentujący może na poparcie swojej tezy wskazać jakąkolwiek osobę, która podziela jego pogląd. Argument $\mathrm{z}$ autorytetu zakłada natomiast odwołanie się nie do kogokolwiek, ale do autorytetu właśnie. Zatem warunkiem jaki należy nałożyć na $x$ jest, by był on autorytetem. Konieczne jest również uwzględnienie ustaleń Bocheńskiego co do relacyjnego charakteru autorytetu [por. Tokarz 2006, s. 175]:

$$
\begin{aligned}
& x \text { twierdzi, ze } p \\
& p \text { należy do d } \\
& x \text { jest autorytetem } w d \\
& \hline p
\end{aligned}
$$

gdzie $d$ jest dziedziną, w której $x$ jest autorytetem. 
Bardziej formalnie można to zapisać następująco:

$$
\begin{aligned}
& T(x, p) \\
& p \in D \\
& A(x, D) \\
& \hline p
\end{aligned}
$$

gdzie $x$ jest osobą, na którą się powołujemy, $A$ predykatem dwuargumentowym jest autorytetem $w$ dziedzinie $D, T$ predykatem dwuargumentowy twierdzi, że $p$.

Schemat tej postaci uwzględnia już relacyjność autorytetu, ale traktuje się w nim autorytet jako relację dwuargumentową między podmiotem a dziedziną (obiektywistycznie), tym czasem, jak pokazał Bocheński, autorytet jest relacją trójargumentową - autorytet nie jest autorytetem w ogóle (dla wszystkich), ale tylko dla określonego zbioru podmiotów, o podmiocie autorytetu zaś powyższy schemat nic nie mówi.

Problem podmiotu jest natomiast kluczowy w przypadku argumentu $\mathrm{z}$ autorytetu. Bowiem jako taki argument $\mathrm{z}$ autorytetu nie jest rozumowaniem zawieszonym w próżni ale formułowanym na potrzeby konkretnej sytuacji komunikacyjnej. Przed nadawcą argumentu staje tedy problem, jak dobrać autorytet - kto ma być jego podmiotem? Odruchowo wskazuje się autorytet uznawany przez siebie, by jednak argument z autorytetu okazał się skuteczny (przy jednoczesnym zachowaniu logiczno-pragmatycznej poprawności) wystarczy by autorytet był uznawany przez rozmówcę (adresata argumentu) innymi słowy, by odbiorca był przedmiotem autorytetu na który w argumencie się powołujemy. Odsłania się tu pewien problem etyczny - czy uczciwie jest powoływać się na autorytet, którego samemu się nie uznaje, ale który uznawany jest przez rozmówcę? - nie jest to jednak przedmiotem prowadzonych w tej chwili analiz, a z logiczno-pragmatycznego punktu widzenia, żeby przekonać, wystarczy by odbiorca był przedmiotem autorytetu. Po uwzględnieniu trójczłonowego charakteru relacji autorytetu można przedstawić następujący schemat rozumowania $\mathrm{w}$ argumencie $\mathrm{z}$ autorytetu:

$$
\begin{aligned}
& A(x, y, D) \\
& T(x, p) \\
& p \in D \\
& p
\end{aligned}
$$

gdzie $y$ jest przedmiotem autorytetu (w szczególności my sami) zaś $A$ predykatem trójargumentowy bycia autorytetem przez..., dla ..., w dziedzinie $D$. 
W szczególnym przypadku odbiorcą argumentu z autorytetu może być jego nadawca - w sytuacji, o której wspomniano na początku - kiedy sami wyrabiamy sobie pogląd w jakiejś sprawie, lub próbujemy wyłącznie na własny użytek rozstrzygnąć jakąś kwestię. Wtedy w powyższym schemacie będziemy osobą $y$.

W przeciwnym wypadku - gdy nadawca argumentu nie jest jego odbiorcą i przy założeniu że powołujemy się na autorytet którego nie jesteśmy przedmiotami - schemat ten prowadzi do absurdalnej konkluzji, twierdzi bowiem, że jeśli jakieś dwie osoby i dziedzina są związane relacją autorytetu, to jest tak jak głosi podmiot; innymi słowy, jeśli idiota jest dla kogoś autorytetem w jakiejś dziedzinie, to znaczy, że jest tak jak ów idiota twierdzi (o ile twierdzenie to należ do dziedziny).

Wobec tego należy osłabić wniosek nadając mu postać $-T(y, p)$. Wtedy całe rozumowanie przybiera postać:

$$
\begin{aligned}
& A(x, y, D) \\
& T(x, p) \\
& p \in D \\
& \hline T(y, p)
\end{aligned}
$$

Schemat tej postaci pokazuje de facto to, co stwierdza Bocheński w swej teorii, że przedmiot autorytetu przyjmuje do wiadomości to, co podmiot stwierdza, a co należy do dziedziny, w której podmiot jest przez przedmiot uznany za autorytet. Jednak interpretując ten schemat w kontekście argumentu $z$ autorytetu należy zwrócić uwagę, że tego rodzaju rozumowanie przeprowadzane jest przez nadawcę argumentu, a nie przez odbiorcę (czyli przedmiot autorytetu). Oznacza to, że nadawca argumentu, o ile jego celem jest przede wszystkim przekonanie odbiorcy, intuicyjnie pojmuje autorytet podobnie do Bocheńskiego i wykorzystuje mechanikę oddziaływania autorytetu, a argument sprowadza się wtedy do wskazania odbiorcy relacji w której pozostaje wobec autorytetu, resztę pracy wykonuje niejako za nadawcę sama relacja autorytetu.

W tym momencie okazuje się, że punkt ciężkości spoczywa na uznawaniu autorytetu. Gdyby bowiem odbiorca nie był przedmiotem autorytetu (tzn. nie uznawał autorytetu, na który powołuje się nadawca), wtedy argument byłby nieskuteczny. Pojawia się wobec tego pytanie - co sprawia, że odbiorca uznaje autorytet? Oczywiście może być tak, że jest on osobą nader naiwną tudzież łatwowierną i bezrefleksyjnie uznaje autorytet, zakładamy jednak, że odbiorca jest osobą racjonalną i krytyczną. Wobec tego należy przypuszczać, że za uznaniem autorytetu kryją się jakieś racjonalne przesłanki. Wyliczyć można co 
najmniej kilka takich przesłanek: (1) dziedzina musi być uznana, to wyklucza np. astrologię, ale dopuszcza np. biologię, (2) osoba na którą się powołujemy musi być kompetentna $\mathrm{w}$ tej dziedzinie, np. absolwent biologii, albo osoba która rzetelnie się biologią interesuje, (3) ważne jest by wśród osób kompetentnych w tej dziedzinie panowała co do bronionej tezy zgoda, (4) autorytet musi być jasno wskazany np. ,prof. Janusz Majewski”, ale nie ,jakiś profesor", (5) autorytet nie może być w konflikcie interesów np. dietetyk, który wystąpił w reklamie masła będzie prawdopodobnie kiepskim autorytetem jeśli chodzi o wskazanie przewagi margaryny nad masłem [por. Tokarz 2006, s. 176]. Wszystkie wyliczone tu przesłanki mogą stanowić przedmiot odrębnego uzasadnienia, możemy powoływać się na uznanie jakim przywoływany autorytet się cieszy, na jego dorobek naukowy, na długoletnią praktykę w danej dziedzinie, na sukcesy, możemy uzasadniać jego prawdomówność etc. Wszystko to sprawia, że uzasadnienie autorytetu samo w sobie może też być procesem zupełnie racjonalnym, a przesłanki do uznania autorytetu - obiektywne. Co za tym idzie - sam argument z autorytetu może okazać się argumentem wysokiej próby.

Jeżeli jednak zgodzimy się, że argument $\mathrm{z}$ autorytetu jest nie tylko skuteczny, ale i w pełni racjonalny, niemalże dedukcyjny, jeśli tylko przygotowany jest rzetelnie, a $\mathrm{z}$ drugiej strony, co właściwe logikom i filozofom, ponad skuteczność postawimy racjonalizm i obiektywizm, to trudno wyobrazić sobie sytuację, w której odbiorca argumentu uznawałby autorytet, a nadawca go odrzucał (pomijamy tu wszelkie względy psychologiczne i niemerytoryczne, które również mogą wpływać na to, kogo za autorytet się uznaje, a kogo nie). Uznanie autorytetu profesora biologii jeśli chodzi o biologię jest prawdopodobnie jedyną racjonalną postawą, jaką mogą przyjąć osoby niemające pojęcia o biologii. Jeśli więc nadawca i odbiorca nie są kompetentni w dziedzinie, o której mówią, a zarazem są racjonalni i obiektywni, to uznają te same autorytety w tej dziedzinie.

Idąc tym tropem należy stwierdzić, że argument $\mathrm{z}$ autorytetu, jeśli jest rzetelny, a jego nadawca - roztropny i obiektywny, będzie tak samo przekonujący dla odbiorcy, jak i dla nadawcy (oczywiście wykluczamy w całości naszych rozważań sytuację, w której nadawca argumentu sam jest autorytetem przemawiającym tonem w rodzaju - ,jestem magistrem, mnie słuchajcie"). Jest to mocny argument na rzecz uznania przytoczonego wcześniej, ale roboczo odrzuconego schematu podanego przez Tokarza. Formuła ta choć odbiega od ustaleń Bocheńskiego i nie uwzględnia trójargumentowości relacji autorytetu, pod pewnymi warunkami okazuje się trafnie ujmować rozumowanie jakim jest w istocie ta forma argumentu. 
Jak pokazaliśmy uznanie autorytetu jest procesem racjonalnym. Podobnie twierdzi Bocheński. Implicite w swojej pracy pokazuje, że autorytet jest zjawiskiem raczej obiektywnym, niż subiektywnym. Owszem by zaistniał konieczne jest uznanie ze strony przedmiotu, ale jeśli zgodzimy się, że uznanie autorytetu jest procesem racjonalnym i zależy w sytuacji idealnej głównie od przesłanek obiektywnych, to musimy zgodzić się również, że nie zależy ono od kaprysów ze strony przedmiotu, ale przedmiot poddany jest swego rodzaju konieczności uznania kogoś za autorytet.

\section{PODSUMOWANIE}

Przed argumentacją stawia się dwa zadania - poprawność i skuteczność. Nie muszą one iść ze sobą w parze: bardzo skuteczny może być argument z punktu widzenia logiki kompletnie bezwartościowy, z drugiej strony argument poprawny logicznie może być na tyle mało przejrzysty, lub skomplikowany, że dla większości odbiorców będzie mało przekonujący.

Podobnie rzecz ma się z argumentem z autorytetu. Jest on psychologicznie rzecz biorąc bardzo skuteczny (co dowiodły choćby eksperymenty Stanleya Millgrama), ale również jak pokazały to powyższe analizy, może być logicznie poprawny, jeśli spełnia stosowne kryteria.

Analiza argumentu z autorytetu w każdej z perspektyw z osobna (ze względu na skuteczność i ze względu na poprawność) daje nieco odmienne wyniki.

Kiedy rozumieć będziemy argumentację przede wszystkim jako metodę przekonywania, wtedy musimy założyć, że nadawca ma na celu wyłącznie skuteczną perswazję, nie ma znaczenia, czy sam uznaje autorytet na który się powołuje. Nie ma znaczenia, czy argumentacja jest zasadna, ważne by była skuteczna. Autorytet nie musi być godny zaufania, wystarczy jedynie by odbiorca argumentu go przyjął. Okazuje się wtedy, że argument z autorytetu potwierdza tezę wyłącznie w subiektywnym oglądzie odbiorcy; innymi słowy - nie potwierdza tezy, a jedynie prowadzi do przyjęcia jej przez odbiorcę. Formalnie struktura takiego argumentu ma postać:

$$
\begin{aligned}
& A(x, y, D) \\
& T(x, p) \\
& p \in D \\
& \hline T(y, p)
\end{aligned}
$$

bo choć nadawca otwarcie tego nie przyznaje, to zakłada wyłącznie zmianę poglądów odbiorcy, a niekoniecznie przyjmuje argumentowaną tezę, skoro 
sam może nie uznawać autorytetu. Można posunąć się jeszcze krok dalej. Podmiot autorytetu nie musi być autorytetem, ważne jedynie by przedmiot twierdził, że podmiot jest autorytetem, wtedy uzyskujemy schemat następującej postaci:

$$
\begin{aligned}
& T(y, A(x, D)) \\
& T(x, p) \\
& p \in D \\
& T(y, p)
\end{aligned}
$$

Oczywiście w subiektywnej perspektywie odbiorcy rozumowanie ma postać:

$$
\begin{aligned}
& T(x, p) \\
& p \in D \\
& A(x, D) \\
& \hline p
\end{aligned}
$$

Rozbieżność między rozumowaniem nadawcy i odbiorcy wywołanym przez tak konstruowany argument każe wątpić w rzetelność takiej argumentacji i podaje w wątpliwość jej uczciwość.

Kiedy rozumieć będziemy argumentację przede wszystkim jako sposób dowodzenia, wtedy nadawca staje się osobą, która przedstawia dowód tezy. Można sądzić, że argument z autorytetu jest słabym argumentem (jak twierdzili scholastycy), jest to jednak przekonanie, które ciężko dziś przyjąć. Argument $\mathrm{z}$ autorytetu jak się okazuje jest najpowszechniejszym argumentem jakim posługujemy się przyjmując i przekazując wiedzę i poglądy, a przede wszystkim może być niezwykle trafny z punktu widzenia logiki, niemalże dedukcyjny, jeśli tylko spełnia stosowne formalne i materialne wymogi. Okazuje się bowiem, że autorytet da się racjonalnie i obiektywnie uzasadniać, wobec czego uznanie autorytetu nie wynika z jakiegoś kaprysu woli, ale jest swego rodzaju koniecznością - racjonalnie myślący człowiek nie-biolog będzie uznawał autorytet profesora biologii, a na śmieszność narazi się, gdy odrzuci go bez wskazania dostatecznej przyczyny. Skoro uznanie autorytetu jest procesem racjonalnym, opartym na obiektywnych przesłankach, to argument przywołujący wypowiedź autorytetu również będzie racjonalny i obiektywny. Przyjęcie, że autorytet jest trójargumentową relacją między podmiotem, przedmiotem i dziedziną, może łatwo skłonić do błędnego przeświadczenia, że autorytet jest zjawiskiem relatywnym mocno zależnym od uznania ze strony przedmiotu. Owszem rzeczywiście zależy od uznania ze strony przedmiotu, ale uznanie to jest racjonalne i oparte na obiektywnych przesłankach, jest 
koniecznością. Jeśli istnieją mocne przesłanki by kogoś uznać za autorytet w jakiejś dziedzinie, to głupotą będzie odrzucać ten autorytet. Wobec tego uznanie autorytetu zależy od przedmiotu nie w większym stopniu niż od podmiotu i dziedziny.

Ostatni schemat nie uwzględnia przedmiotu autorytetu właśnie dlatego, że jego znaczenie nie jest $\mathrm{w}$ żadnym sensie szczególne. Jeśli za uznaniem autorytetu przemawiają obiektywne przesłanki, to nawet jeśli autorytet nie będzie miał swego przedmiotu, argument przywołujący go będzie logicznie prawomocny. Zasadnicza różnica jaką pozwala stwierdzić badanie argumentu $\mathrm{z}$ autorytetu widoczna jest $\mathrm{W}$ następniku implikacji $\mathrm{w}$ przedstawionych formułach.

Argument skuteczny prowadzi do zmiany przekonań odbiorcy - argument $\mathrm{z}$ autorytetu $\mathrm{z}$ pewnością jest bardzo skutecznym argumentem (względy psychologiczne). Argument poprawny jest prawomocny logicznie. Jak widać, wbrew pozorom, argument $\mathrm{z}$ autorytetu może być całkowicie prawomocny logicznie i mieć wysoką wartość poznawczą.

$\mathrm{Z}$ idealną sytuacją mamy do czynienia gdy argumentacja oparta na argumencie $\mathrm{z}$ autorytetu jest jednocześnie poprawna i skuteczna. Argument $\mathrm{z}$ autorytetu jest $\mathrm{w}$ stanie sprostać obu tym wymogom jednocześnie, w ujęciu formalnym wygląda to następująco:

$$
\frac{\frac{K(x, D)}{A(x, D)} \quad \begin{array}{c}
T(x, p) \\
p \in d
\end{array}}{p \wedge T(y, p)}
$$

gdzie $\mathrm{K}$ jest dwuargumentową relacją kompetencji... w dziedzinie... .

Argument $\mathrm{z}$ autorytetu, który będzie reprezentował taką lub podobną formalną strukturę, jest najlepszą możliwą postacią argumentu $\mathrm{z}$ autorytetu.

\section{BIBLIOGRAFIA}

Bocheński, J. M. (1974), Co to jest autorytet?, [w:] Logika i filozofia. Państwowe Wydawnictwo Naukowe.

Tokarz, M. (2006), Argumentacja, perswazja, manipulacja. Gdańskie Wydawnictwo Psychologiczne.

Szymanek, K. (2008), Sztuka argumentacji. Stownik terminologiczny. Wydawnictwo Naukowe PWN. 


\section{ARGUMENT FROM AUTHORITY. FORMAL ASPECTS}

(Abstract)

The article presents an analysis of the argument from authority. The argument seems weak, because it is not supported by reliable reasoning but by knowledge of somebody else. However, the presented analysis shows that this contention is not obvious. The key element of the argument from authority is the authority to which we refer. If the authority is unquestionable the argument seems accurate. The argument from authority is very effective for psychological reasons, but if well-constructed, it can be rational and logically correct. Everything depends on the reasons why an authority is invoked in the given circumstances. The acceptance of authority is not only the problem of psychological reasons and motivations, but very often it is also necessary from rational point of view - in certain situations it is even irrational to reject the authority. It is therefore clear that the argument from authority correctly applied and supported by a reasonable authority can be considered as rational.

\section{KEYWORDS}

Authority, argumentation, argument form authority, Milgram, Bochenski, Tokarz 